\title{
MANAJEMEN PEMBELAJARAN EKSTRAKURIKULER DALAM MENINGKATKAN MUTU MADRASAH
}

\author{
Nur Arifah \\ Institut Agama Islam Bani Fattah Jombang, Indonesia \\ E-mail: alifahmy09@gmail.com
}

\begin{abstract}
Based on constitution number 20 year 2003 about National Education System and Permendikmas number 39 year 2008 about coaching students, chapter one, clause one, paragraph (a), which reads develop potential students in an optimal and integrated matching with the talent, enthusiasm, and creativity. Paragraph (c) reads actualize the potential of students in achieving seeded according to their talents and interests. Based on this, the school needs to establish a special container to improve the talent, potential and creativity of students so as to support school improvement.
\end{abstract}

Keywords: Extracurricular Learning Management, Quality of School. 


\section{Pendahuluan}

Pendidikan nasional yang berdasarkan Pancasila dan Undang-Undang Dasar Negara Republik Indonesia tahun 1945 berfungsi mengembangkan kemampuan dan membentuk watak serta peradaban bangsa yang bermartabat dalam rangka mencerdaskan kehidupan bangsa, bertujuan untuk mengembangkan potensi peserta didik agar menjadi manusia yang beriman dan bertakwa kepada Tuhan Yang Maha Esa, berakhlak mulia, sehat, berilmu, cakap, kreatif, mandiri, dan menjadi warga negara yang demokratis serta bertanggung jawab dan juga perlu adanya peningkatan mutu pendidikan yang diarahkan untuk meningkatkan kualitas manusia Indonesia seutuhnya melalui olah hati, olah pikir, dan olahraga agar memiliki daya saing dalam menghadapi tantangan global. Untuk mencapai tujuan tersebut pendidikan dilakukan melalui kegiatan kurikuler dan kegiatan ekstrakurikuler.

Dalam dunia pendidikan dikenal ada dua kegiatan yang cukup elementer, yaitu kegiatan kurikuler dan kegiatan ekstrakurikuler. ${ }^{1}$ Kegiatan kurikuler merupakan kegiatan pokok pendidikan yang di dalamnya terjadi proses belajar mengajar antara peserta didik dan guru untuk mendalami materi ilmu pengetahuan yang berkaitan dengan tujuan pendidikan dan kemampuan yang hendak diperoleh peserta didik. Sedangkan yang kedua merupakan kegiatan yang dilakukan dalam rangka mengembangkan aspek-aspek tertentu dari apa yang ditemukan pada kurikulum yang sedang dijalankan, termasuk yang berhubungan dengan bagaimana penerapan sesungguhnya dari ilmu pengetahuan yang dipelajari oleh peserta didik sesuai dengan tuntutan kebutuhan hidup mereka maupun lingkungan sekitarnya. ${ }^{2}$

Sesuai dengan Permendikias RI Nomor 39 Tahun 2008 tentang Pembinaan Kesiswaan, bahwa "Pembinaan kesiswaan dilaksanakan melalui kegiatan ekstrakurikuler dan kegiatan kurikuler".

Madrasah maupun sekolah umum sebagaimana lembaga pendidikan diselenggarakan dalam rangka mempersiapkan generasi pelopor untuk mewujudkan cita-cita di atas. Karena itu, lulusan bermutu, berkualitas, dan berkepribadan luhur haruslah dihasilkan melalui proses pendidikan baik di madrasah maupun sekolah umum. Selain lebih diarahkan pada hasil belajar (out put) prinsip dasar pendidikan juga diarahkan pada proses

1 Departemen Agama, Panduan Kegiatan Ekstrakurikuler Pendidikaan Agama Islam, (Jakarta: Dirjen Kelembagaan Islam, 2005), 3.

2 Mulyono, Manajemen Administrasi dan Organisasi Pendidikaan, (Yogyakarta: Arruzmedia, 2008), 186. 
belajar mengajar yang terencana, sistematis dan berorientasi pada pengembangan sumber daya manusia peserta didik. Dengan demikian proses belajar mengajar sebaiknya diperlukan sebagai suatu kegiatan pendidikan yang melibatkan berbagai unsur, sehingga mencapai hasil yang optimal. Dengan demikian proses pembelajaran dan pengajaran di madrasah maupun sekolah umum hendaknya menjadi aktifitas pendidikan yang bersifat interaktif, partisipatif, dan fleksibel yang mampu memberikan hasil yang memuaskan dan diharapkan oleh masyarakat.

Jelaslah bahwa keberhasilan pendidikan tidak hanya dilakukan dengan kegiatan kurikuler saja, melainkan kegiatan ekstrakurikuler juga sangat menunjang keberhasilan pendidikan di Indonesia.

\section{Konsep Manajemen}

a) Pengertian Manajemen

Manajemen adalah seni memperoleh hasil melalui berbagai kegiatan yang dilakukan oleh orang lain. Definisi tersebut memberi petunjuk bahwa menejemen dapat dilihat dari empat sudut pandang. Pertama, situasional dalam arti penerapan berbagai teori harus dibarengi oleh seni menggerakkan orang lain agar mau dan mampu berkarya demi kepentingan organisasi. Kedua, manajemen selalu berkaitan dengan organisasional ketika terdapat sekelompok orang yang menduduki berbagai jenjang tingkat kepemimpinan dan sekelompok orang lain yang tanggung jawab utamanya adalah menyelenggarakan berbagai kegiatan operasional. Pandangan ini sangat mendasar karena keberhasilan seseorang yang menduduki jabatan manajerial tidak lagi diukur dari keterampilan menyelenggarakan kegiatan operasional, melainkan dari kemahiran dan kemampuannnya menggerakkan orang lain dalam organisasi. Ketiga, keberhasilan organisasi merupakan gabungan antara kemahiran manajerial dan keterampilan teknis para pelaksana kegiatan operasional. Keempat, kelompok manajerial dan kelompok pelaksana mempunyai bidang tanggung jawab masing-masing yang secara konseptual dan teoritikal dapat dipisahkan tetapi secara operasional menyatu dalam berbagai tindakan nyata dalam rangka pencapaian tujuan yang telah ditetapkan sebelumnya. ${ }^{3}$

Manajemen disebut sebagai applied science (ilmu aplikatif yang dijabarkan menjadi sebuah proses tindakan meliputi beberapa hal

\footnotetext{
${ }^{3}$ Sondang P. Siagian, Manajemen Sumber Daya Manusia, (Jakarta: Bumi Aksara, 2005), 1.
} 
sebagai berikut: ${ }^{4}$

1) Perencanaan (planning): mencakup penetapan tujuan, standar, penentuan aturan-prosedur, dan pembuatan rencana serta ramalan (prediksi) apa yang diperkirakan terjadi.

2) Pengorganisasian (organizing): meliputi pemberian tugas yang terpisah kepada masing-masing pihak, membentuk bagian, mendelegasikan atau menetapkan jalur wewenang/tanggung jawab dan sistem komunikasi, serta mengkoordinir kerja setiap bawahan dalam suatu tim kerja yang solid dan terorganisir.

3) Penggerakan (actuating): setelah kegiatan perencanaan dan pengorganisasian pimpinan perlu dapat menggerakkan kelompok secara efisien dan efektif kearah pencapaiaan tujuan dalam pengerakan kelompok ini pimpinan menggunakan berbagai sarana meliputi: komunikasi, kepemimpinan, perundingan-perundingan, pemberian intruksi dan lain-lain. Dengan penggerakan ini pimpinan berusaha menjadikan organisasi bergerak dan berjalan secara aktif dan dinamis.

4) Pengawasan (controlling): pengawasan bisa juga disebut pengendalian atau evaluasi ketika organisasi telah bergerak dan berjalan pimpinan harus selalu mengadakan pengawasan atau pengendalian agar gerakan atau jalannya organisasi benar-benar sesuai dengan rencana yang telah ditetapkan.

Dari pengertian di atas dapat dipahami bahwa manajemen adalah serangkaian kegiatan perencanaan, pengorganisasian, penggerakan dan pengawasan untuk mencapai tujuan yang teklah ditetapkan dalam wadah organisasi.

b) Fungsi Manajemen Pendidikan

Sejalan dengan sejarah perkembangan dan situasi penerapannya, manajemen meliputi berbagai fungsi yang merupakan rangkaian berbagai kegiatan yang telah ditetapkan dan memiliki hubungan yang saling ketergantungan antara satu dengan yang lainnya serta dilaksanakan oleh orang-orang lembaga atau bagian lainnya yang diberi tugas untuk melaksanakan kegiatan tersebut.

Adapun fungsi manajemen pendidikan tersebut adalah sebagai berikut:

1) Fungsi merencanakan (Planning)

Perencanaan dapat diartikan sebagai suatu proses untuk menentukan tujuan serta sasaran yang ingin dicapai dan mengambil

\footnotetext{
${ }^{4}$ A. Halim, Manajemen Pesantren, (Yogyajarta: LKiS, 2005), 71.
} 
langkah-langkah strategis guna mencapai tujuan tersebut..$^{5}$ Melalui perencanaan seseorang pemimpin akan dapat mengetahui apa saja yang harus dilakukan dan bagaimana cara melakukannya. ${ }^{6}$ Perencanaan atau planning merupakan kegiatan awal dalam sebuah pekerjaan dalam bentuk memikirkan hal-hal yang terkait dengan pekerjaan itu agar mendapat hasil yang optimal. Oleh karena itu perencanaan merupakan suatu keniscayaan, keharusan disamping sebagai sebuah kebutuhan.

Hal di atas dapat menjadi acuan bagi kepala sekolah maupun guru untuk membuat sesuatu perencanaan yang baik, dalam hal ini perencanaan yang baik harus memenuhi persyaratan berikut ini:

a. Dibuat berdasarkan data yang ada dan dipikirkan pula kejadiankejadian yang mungkin timbul sebagai akibat tindakan pelakanan yang diambil.

b. Harus dibuat oleh orang-orang yang betul-betul memahami teknik perencanaan.

c. Rencana harus disertai oleh suatu perincian yang teliti dan detail.

d. Perencanaan harus bersifat sederhana kesederhanaan di sini nampak pada kemudahan pemahaman dan pelaksanaannya oleh pihak yang memerlukan.

e. Perencanaan harus dapat mengikuti perkembangan kemajuan masyarakat, situasi dan kondisi.

f. Perencanaan dilakukan secara terus-menerus dan berkelanjutan.

g. Perencanaan hendaknya memikirkan peningkatan dan perbaikan-perbaikan untuk kesempurnaan dimasa yang akan datang.

h. Perencanaan harus terdapat tempat pengambilan keputusan resiko bagi setiap kemungkinan yang muncul di kemudian hari.

2) Pengorganisasian (organizing)

Pengorganisasian adalah sebagai berikut: ${ }^{8}$

a. Penentuan sumber daya dan kegiatan yang dibutuhkan untuk

${ }^{5}$ Amirullah dan Rindyah Hanafi, Pengantar Manajemen, (Yogyakarta: Graha Ilmu, 2002), 9.

${ }^{6}$ Didin Hafidhuddin \& Hendri Tanjung, Manajemen Syari'ab Dalam Praktik, Jakarta: Gema Insani Press, 2003), 77.

7 Burhanuddin, Analisis Administrasi, Manajemen dan Kepemimpinan Pendidikan, (Jakarta: Bumi Aksara, 1994), 171.

8 T. Hani Handoko, Manajemen Sumber Daya Manusia, (Bandung: Salemba Empat, 2003), 19. 
mencapai tujuan organisasi.

b. Proses perancangan dan pengembangan suatu organisasi yang akan dapat membawa hal-hal tersebut ke arah tujuan.

c. Penugasan tanggung jawab tertentu dan kemudian.

d. Pendelegasian wewenang yang diperlukan kepada individuindividu untuk melaksanakan tugas-tugasnya. Ditambahkan pula bahwa pengorganisasian ialah pengatuaran kerja bersama sumber daya keuangan fisik dan manusia dalam organisasi, serta penyusunan struktur organisasi yang sesuai dengan tujuan organisasi, sumber daya yang dimilikinya, dan lingkungan yang melingkupinya.

Agar pengorganisasian dapat berlangsung dengan baik dan mencapai tujuan bersama dalam tata kerja yang baik, maka diperlukan prinsip-prinsip sebagai berikut:

a. Masing-masing unit mempunyai kesadaran yang tinggi untuk sanggup menerima tujuan yang telah ditetapkan sehingga kegiatan setiap unit diarahkan ke tujuan bersama.

b. Struktur organisasi harus sederhana agar jalur kerja dan jalur hubungan dapat nampak jelas, dan tidak terlalu banyak orang yang terlibat dalam tanggung jawab, karenan keterlibatan orang yang terlalu banyak akan menghambat kerja dan merupakan suatu pemborosan besar.

c. Pembuatan struktur organisasi harus menggambarkan adanya suatu perintah, adanya keseimbangan tugas antara unit dan sebagai dampak, adanya kesederhanaan wewenang dan tanggung jawab agar mengurangi "span ofcontrol".

d. Pembagian organisasi ke dalam bidang atau unit harus diatur sedemikian rupa sehingga tidak ada unit yang tanpa tugas sebaliknya tidak ada dua unit atau lebih yang mempunyai tugas yang sama.'

Sedangkan manfaat daripada pengorganisasian adalah: ${ }^{10}$

a. Setiap orang akan mengerti akan tugas-tugasnya masing-masnig.

b. Memperjelas hubungan kerja para anggota organisasi.

c. Terdapat kooordinasi yang tepat antara unit kerja.

d. Menggunakan tenaga kerja sesuai dengan kemampuan dan minat.

${ }^{9}$ Suharsimi Arikunto, Prosedur Penelitian: Suatu Pendekatan Praktek, Jakarta: Rieneka Cipta, 2002), 39-40.

${ }^{10}$ Burhanuddin, Analisis Administrasi, Manajemen dan Kepemimpinan Pendidikan..., 205. 
e. Agar kegiatan administrasi dan manajemen dapat dilakukan secara efektif dan efesien.

3) Melakasanakan (actuating)

Fungsi ketiga dalam manajemen adalah menggerakkan yaitu tindakan yang dilakukan agar sumber-sumber daya bergerak melaksanakan kegiatan mencapai tujuan. Kegiatan dalam penggerakan adalah ikut serta berperan dalam menentukan keputusan atau aturan, memimpin dan memberikan tantangan bagi anggota, mengembangkan sumber daya manusia, imbalan berupa penghargaan dan upah, memuaskan kebutuhan pegawai melalui tantangan untuk meningkatkan hasil karyanya, memperbaiki pelaksanaan kegiatan sesuai dengan hasil danmenentukan kesenjangan (deviasi) antara pelaksanaan dengan standard dan rencana. ${ }^{11}$

4) Pengawasan (Controlling)

Fungsi pengawasan (Controling) adalah suatu proses untuk memonitoring aktifitas-aktifitas dalam menentukan bahwa aktifitas tersebut sedang diselesaikan secara terencana dan baik terhadap, masalah yang signifikan.

Definisi di atas memberikan pemahaman bahwa fungsi pengawasan dalam manajemen (controlling) adalah suatu usaha yang sistematik untuk:

a. Membangun standar pelaksanaan.

b. Mendesain sistem umpan balik informasi.

c. Membandingkan pelaksanaan yang aktual.

d. Menentukan ada tidaknya kesenjangan perencanaan.

e. Mengukur tingkat signifikansi dalam mengimplementasikan sumber daya yang akan digunakan secara efektif dan efesien dalam mencapai tujuan bersama.

Definisi ini memberi gambaran bahwa fungsi pengawasan (controlling) adalah suatu proses untuk menjamin penyelesain masalah yang efesien dalam tujuan organisasi, yang melibatkan standard, membandingkan pelaksanaan yang terukur dengan standard yang dibangun, serta menguatkan kesuksesan dan memperbaiki kekurangan.

5) Memotivasi (motivating)

Motivasi menyangkut perilaku manusia dan merupakan salah

${ }^{11}$ George R. Terry, Principles of Management, Richard D. Irwin, (INC. Homewood, JrwinDorsey Limited Georgetown, Ontario L7G 4B3, 1977), 371. 
satu unsur dalam manajemen, motivasi juga merupakan keinginan yang terdapat pada seseorang individu yang merangsangnya untuk melakukan tindakan tindakan atau sesuatu yang menjadi dasar atau alasan seseorang dalam berperilaku. Motivasi kerja dapat diartikan sebagai keinginan-keinginan atau kebutuhan-kebutuhan yang melatarbelakangi seseorang sehingga terdorong untuk bekerja.

Apabila kita mempelajarai berbagai macam pandangan dan pendapat tentang masalah motivasi, maka kita dapat menarik kesimpulan bahwa:

a. Motivasi berkaitan dengan perilaku dan kinerja.

b. Motivasi mencakup pengarahan kearah tujuan tertentu.

c. Dalam hal mempertimbangkan motivsasi perlu kita memperhatikan faktor-faktor fisiologikal, psikologikal, dan lingkungan (environmental), sebagai faktor-faktor penting yang dapat mempegaruhi segala sesuatu yang menjadi aktifitas manusia.

Kesimpulan di atas kita dapat memahami bahwa motivasi adalah merupakan suatu kekuatan potensial yang ada pada diri seseorang, yang dapat dikembangkan sendiri atau dikembangkan oleh kekuatan luar yang pada intinya berkisar pada imbalan, yang dapat mempengaruhi hasil kinerjanya secara potensial atau negatif, yang mana tergantung pada situasi dan kondisi yang dihadapi orang yang bersangkutan.

c) Prinsip-Prinsip Manajemen Pendidikan

Prinsip manajemen yang digunakan oleh seorang pimpinan untuk mencegah adanya kesalahan-kesalahan dalam melakukan pekerjaan. Sebagaimana halnya bahwa prinsip merupakan pernyataan mendasar sebagai kebenaran umum yang dijadikan pedoman dalam berfikir dan bertindak. Prinsip-prinsip dalam manajemen terdapat empat belas prinsip, prinsip tersebut adalah: ${ }^{12}$

a. Adanya pembagian kerja (Divison of work).

b. Adanya wewenang dan tanggung jawab yang jelas (Authority and responibilities).

c. Memiliki prinsip (Dicipline).

d. Kesatuan komando (Unity of commad).

e. Kesatuan arahan (Unity of direction).

f. Penyesuaian kepentingan individu dengan kepentingan umum, atau mengutamakan kepentingan umum daripada individu (Subordination

${ }^{12}$ Harold Koontz, Management, (New York: McGraw Hill, 1984), 36. 


\section{of individual interest to general interest).}

g. Pemberian kompensasi terhadap anggota organisasi (Remuneration of personal).

h. Adanya sentralisasi (Centralization).

i. Rentang kendali (Scalarcabin).

j. Adanya perintah (Order).

k. Pemerataan dan keadilan (Equity).

1. Stabilitas personil (Stability of tenure personal)

$\mathrm{m}$. Memiliki inisiatif atau prakarsa (Initiative).

n. Serta semangat tim (Spirit the corps).

Keempat belas prinsip ini tentu saja akan berlaku juga dalam bidang manajemen pendidikan.

\section{Manajemen Pembelajaran Ekstrakurikuler}

Sebagai upaya peningkatan sumber daya manusia (bumam resources) pada dasarnya pendidikan di sekolah maupun madrasah bertujuan untuk mengembangkan aspek-aspek kemanusiaan peserta didik secara utuh, yang meliputi aspek kedalaman spiritual, aspek perilaku, aspek ilmu pengetahuan dan inteletaual dan aspek keterampilan.

Sejalan dengan semakin pesatnya tigkat perkembangan saat ini maka tuntutan akan ketersediaan sumber daya manusia semakin tinggi. Dengan demikian kualitas yang memadai dan output merupakan suatu yang harus dihasilkan oleh sekolah maupun madrasah sebagai suatu pendidikan yang tujuan dasarnya adalah menyiapkan manusia-manusia berkualitas baik secara intelektual, integritas, maupun perannya dalam kehidupan bermasyarakat. Untuk itu baik sekolah maupun madrasah harus membekali dirinya dengan kurikulum yang memadai.

Sebagaimana penjelasan di atas, dalam dunia proses pendidikan ada dua hal kegiatan yang cukup elementer, yaitu kegiatan kurikuler dan kegiatan ekstrakurikuler.

1) Pengertian Ekstrakurikuler

Dalam kamus ilmiah popular, kata ekstrakurikuler mempunyai arti kegiatan tambahan di luar rencana pelajaran, atau pendidikan tambahan di luar kurikulum. Dengan demikian kegiatan ekstrakurikuler merupakan kegiatan yang dilakukan di luar kelas dan di luar jam pelajaran (kurikulum) untuk menumbuhkembangkan potensi sumber daya manusia (SDM) yang dimiliki peserta didik, baik berkaitan dengan aplikasi ilmu pengetahuan yang didapatkannya maupun dalam pengertian khusus untuk membimbing peserta didik dalam mengembangkan potensi dan bakat yang ada dalam dirinya melalui 
kegiatan-kegiatan yang wajib maupun pilihan.

Kegiatan ekstrakurikuler adalah kegiatan pelajaran yang diselenggarakan di luar jam pelajaran biasa. Kegiatan ekstrakurikuler ini sering dimaksudkan untuk mengembangkan salah satu bidang pelajaran yang diminati oleh satu kelompok siswa, misalnya olahraga, kesenian, dan berbagai kegiatan keterampilan dan kepramukaan.

Bermacam-macam kegiatan seperti ekstrakurikuler, atau kegiatankegiatan di luar sekolah. Kegiatan itu lebih baik digambarkan sebagai kegiatan di luar kelas hanya sebagai kegiatan-kegiatan siswa. ${ }^{13}$

Adapun yang dimakud dengan manajemen kegiatan ekstrakurikuler adalah seluruh proses yang direncanakan dan diusahakan secara terorganisir mengenai kegiatan sekolah yang dilakukan di luar kelas dan di luar jam pelajaran.

2) Fungsi dan tujuan Pembelajaran Ekstrakurikuler

Sebagai kegiatan pembelajaran dan pengajaran di luar kelas, ekstrakurikuler ini mempunyai fungsi dan tujuan, yakni untuk:

a. Meningkatkan kemampuan peserta didik sebagai anggota masyarakat dalam mengadakan hubungan timbal balik dengan lingkungan sosial, budaya dan alam semesta.

b. Menyalurkan dan mengembangkan potensi dan bakat peserta didik agar dapat menjadi manusia yang berkreativitas tinggi dan penuh dengan karya.

c. Melatih sikap disiplin, kejujuran, kepercayaan, dan tanggungjawab dalam menjalankan tugas.

d. Mengembangkan etika dan akhlak yang mengintegrasikan hubungan dengan Tuhan, Rasul, manusia, alam semesta bahkan diri sendiri.

e. Mengembangkan sensitivitas peserta didik dalam melihat persoalan- persoalan sosial keagamaan sehingga menjadi insan yang produktif terhadap permasalahan sosial keagamaan.

f. Memberikan bimbingan dan arahan serta pelatihan kepada peserta didik agar memiliki fisik yang sehat, bugar, kuat, cekatan dan terampil.

g. Memberi peluang peserta didik agar memiliki kemampuan untuk komunikasi (buman relation) dengan baik, secara verbal dan nonverbal

${ }^{13}$ Hendiyat Soetopo, Kepemimpinan dan Supervisi Pendidikan, (Jakarta: Bina Aksara, 1998), 139. 


\section{Mutu Pendidikan}

Pendidikan yang bermutu dalam artian menghasilkan lulusan yang sesuai dengan harapan masyarakat, baik dalam kualitas pribadi, moral, pengetahuan maupun kompetensi kerja menjadi syarat mutlak dalam kehidupan masyarakat global yang terus berkembang saat ini dan yang akan datang. Masyarakat yang baik hanya dapat dibentuk dengan menampilkan sumber daya manusia (SDM) dengan karakter yang baik. Sumber daya manusia yang berkarakter baik dapat dibentuk melalui pendidikan yang baik. ${ }^{14}$ Dengan demikian mutu pendidikan yang tinggi banyak dipengaruhi oleh mutu SDM kependidikannya.

Rendahnya mutu pendidikan pada berbagai jenis dan jenjang pendidikan sebenarnya merupakan refleksi dari rendahnya mutu SDM kependidikan di perguruan tinggi. ${ }^{15}$

Beberapa ahli yang terkenal dalam dunia pendidikan telah mengembangkan konsep pemikiran mereka tentang masalah mutu pendidikan. Dalam hal ini ada tiga konsep yang dikemukakannya, antara lain:

\section{a. Tinjauan secara sosiologis}

Kualitas pendidikan ternyata bersifat sangat teoritis. Hal ini dikemukakan oleh Beeby dalam kata pengantarnya. Hamalik lebih menekankan pentingnya pendidikan umum dari pada pendidikan vokasional. Pendapat tersebut didasarkan atas pemikiran bahwa pendidkan yang semata-mata mengembangkan keterampilan teknis itu sempit, yang penting adalah mendidik kepribadian manusia yang sekaligus mampu mengerjakan hal-hal praktis.

b. Tinjauan normatif

Yakni tinggi rendahnya mutu pendidikan bergantung pada norma yang dipergunakan. Norma itu erat kaitannya dengan sistem nilai, cara hidup, adat kebiasaan dan hukum yang berlaku dalam suatu masyarakat tertentu. Norma-norma tersebut telah digambarkan dalam tujuan atau cita-cita pendidikan, yakni tujuan intrinsik dan ekstrinsik.

c. Tinjaun kultural

Yakni kualitas pendidikan ditentukan pula oleh kultur nasional. Tiap-tiap negara mempunyai kultur masing-masing. Dalam arti luas, kebudayaan mengandung berbagai dimensi; keluarga, ekonomi, politik, agama atau kepercayaan kepada Tuhan Yang Maha Esa, sosial,

14 Rahman, dkk., Peran Strategis Kepala Sekolah dalam Meningkatkan Mutu Pendidikan, (Sumedang: Alqaprint Jatinangor, 2006), 289.

${ }^{15}$ Rahman, dkk., Peran Strategis......, 290. 
pendidikan, dan rekreasi. Kualitas pendidikan seyogyanya ditilik dari berbagai dimensi tersebut pada tingkat nasional. Dalam hubungan inilah pendekatan cross national atau cross culture akan terjadi. ${ }^{16}$

Merealisasikan pendidikan yang bermutu dituntut penerapan program mutu yang berfokus pada upaya-upaya penyempurnaan mutu seluruh komponen dan kegiatan pendidikan. ${ }^{17}$

Komponen-komponen yang berpengaruh dalam peningkatan mutu di sekolah atau madrasah antara lain: (1) siswa, meliputi: kemampuan lingkungan (sosial, ekonomi, budaya, dan geografis), intelegensi, kepribadian bakat dan minat. (2) Guru, meliputi: kemampuan, latar belakang pendidikan, pengalaman kerja, beban mengajar, kondisi sosial ekonomi, motivasi kerja, komitmen terhadap tugas, disiplin, kreatifitas. (3) Kurikulum, meliputi: landasan program dan pengembangan, garis-garis besar program pengajaran, metode, sarana, teknik penilaian. (4) Sarana dan prasarana, meliputi: alat peraga, alat-alat praktek laboratorium, perpustakaan, ruang keterampilan, ruang UKS, ruang serba guna, ruang tata usaha, ruang BP, gedung dan perabot. (5) Pengelolaan sekolah, meliputi: pengelolaan kelas, guru, siswa, sarana dan prasarana, peningkatan tata tertib/disiplin (kepala sekolah, guru, siswa), kepemimpinan. (6) Proses belajar mengajar, meliputi: penampilan guru, penguasaan materi/kurikulum, penggunaan metode mengajar, pendayagunaan alat/fasilitas pendidikan, penyelenggaraan proses belajar mengajar, evaluasi, pelaksanaan kegiatan ekstrakurikuler dan kurikuler. (7) Pengelolaan dana, meliputi: perencanaan anggaran/dana, pengawasan. (8) Supervisi dan monitoring, meliputi: kepala sekolah sebagai supervisor di sekolahnya, kepala sekolah sebagai supervisor dan pembina lainnya. (9) Hubungan sekolah dengan lingkungan, meliputi hubungan sekolah dengan orang tua siswa, dengan instansi pemerintah, dengan dunia usaha dan tokoh masyarakat dengan lembaga pendidikan lainnya.

Peningkatan mutu pendidikan merupakan sarana pengembangan bidang pendidikan nasional dan bagian integral dari upaya peningkatan kualitas manusia secara kâffah (menyeluruh). Pemerintah dalam hal ini menteri Pendidikan Nasional telah mencanangkan "gerakan peningkatan mutu pendidikan" pada tangal 2 Mei 2002, dan lebih terfokus lagi setelah diamanatkan dalam Undang-undang No. 20 tahun 2003 tentang sistem

\footnotetext{
16 Umar Hamalik, Manajemen Pengembangan Kurikulum, (Bandung: Remaja Rosdakarya, 2007), 36-38.

${ }^{17}$ Nana Syaodikh Sukmadinata, Metodologi Penelitian Pendidikan, (Bandung: Remaja Rosdakarya, 2009), 5.
} 
pendidikan nasional bahwa pendidikan nasional berfungsi mengembangkan kemampuan dan membentuk waktu serta peradaban bangsa yang bermanfaat dalam rangka mencerdaskan kehidupan bangsa. ${ }^{18}$

Pengembangan dan peningkatan mutu pendidikan tidak dapat dikerjakan sendiri melainkan membutuhkan dukungan dan partisipasi berbagai pihak. Baik internal maupun eksternal. Menggali potensi dan kekuatan yang ada di masyarakat dan memanfaatkan seoptimal mungkin. Potensi dan kekuatan tidak selalu berbentuk finansial, tetapi juga material, sumber belajar, tenaga, konsep, dan ide-ide. Organisasi sekolah yang berhasil adalah yang mampu menghimpun semua potensi dan kekuatan internal dan eksternal untuk dimanfaatkan guna mencapai tujuan-tujuan pendidikan. ${ }^{19}$

${ }^{18}$ E. Mulyasa, Menjadi Kepala Sekolah Profesional, (Bandung: Remaja Rosdakarya, 2005), 1.

${ }^{19}$ Nana Syaodikh Sukmadinata, Metodologi Penelitian Pendidikan, 24. 


\section{Kesimpulan}

Pendidikan yang bermutu menjadi syarat mutlak dalam kehidupan masyarakat global yang terus berkembang saat ini dan yang akan datang. Masyarakat yang baik hanya dapat dibentuk dengan menampilkan sumber daya manusia (SDM) dengan karakter yang baik. Sumber daya manusia yang berkarakter baik dapat dibentuk melalui pendidikan yang baik.

Selain melalui kegiatan kurikuler, untuk mendapatkan pendidikan yang baik dan bermutu dapat diperoleh melalui kegiatan ekstrakurikuler yang mana tujuan utamanya adalah mengembangkan potensi siswa secara optimal dan terpadu yang meliputi bakat, minat, dan kreatifitas. Serta mengaktualisasikan potensi siswa dalam mencapai prestasi unggulan sesuai dengan bakat dan minat yang dimilikinya. Sehingga sangat penting bagi sebuah madrasah atau sekolah untuk merencanakan dan mengusahakan secara terorganisir kegiatan tersebut, guna mencapai tujuan utamanya.

Peningkatan mutu pendidikan merupakan sarana pengembangan bidang pendidikan nasional dan bagian integral dari upaya peningkatan kualitas manusia secara kâffah (menyeluruh). Akan tetapi pengembangan dan peningkatan mutu pendidikan tidak dapat dikerjakan sendiri melainkan membutuhkan dukungan dan partisipasi berbagai pihak. Baik internal maupun eksternal. Menggali potensi dan kekuatan yang ada di masyarakat dan memanfaatkan seoptimal mungkin. Potensi dan kekuatan tidak selalu berbentuk finansial, tetapi juga material, sumber belajar, tenaga, konsep, dan ide-ide. Organisasi sekolah yang berhasil adalah yang mampu menghimpun semua potensi dan kekuatan internal dan eksternal untuk dimanfaatkan guna mencapai tujuan-tujuan pendidikan. 


\section{Daftar Pustaka}

Amirullah dan Rindyah Hanafi. Pengantar Manajemen. Yogyakarta: Graha Ilmu, 2002.

Arikunto, Suharsimi. Prosedur Penelitian: Suatu Pendekatan Praktek. Jakarta: Rieneka Cipta, 2002.

Burhanuddin. Analisis Administrasi, Manajemen dan Kepemimpinan Pendidikan. Jakarta: Bumi Aksara, 1994.

Departemen Agama. Panduan Kegiatan Ekstrakurikler Pendidikaan Agama Islam. Jakarta: Dirjen Kelembagaan Islam, 2005.

Didin Hafidhuddin dan Hendri Tanjung. Manajemen Syariab Dalam Praktik. Jakarta: Gema Insani Press, 2003.

Halim, A. Manajemen Pesantren. Yogyajarta: LkiS, 2005.

Hamalik, Umar. Manajemen Pengembangan Kurikulum. Bandung: Remaja Rosdakaiya, 2007.

Handoko, T. Hani. Manajemen Sumber Daya Manusia. Bandung: Salemba Empat, 2003.

Mulyasa, E. Menjadi Kepala Sekolah Profesional. Bandung: Remaja Rosdakaiya, 2005.

Mulyono. Manajemen Administrasi dan Organisasi Pendidikaan. Yogyakarta: Arruzmedia, 2008.

Rahman, dkk. Peran Strategis Kepala Sekolah dalam Meningkatkan Mutu Pendidikan. Sumedang: Alqaprint Jatinangor, 2006.

Siagian, Sondang P. Manajemen Sumber Daya Manusia. Jakarta: Bumi Aksara, 2005.

Soetopo, Hendiyat. Kepemimpinan dan Supervisi Pendidikan. Jakarta: Bina Aksara, 1998.

Sukmadinata, Nana Syaodikh. Metodologi Penelitian Pendidikan. Bandung: Remaja Rosdakarya, 2009. 